Jurnal e-GiGi (eG), Volume 2, Nomor 2, Juli-Desember 2014

\title{
GAMBARAN TINGKAT PENGETAHUAN MASYARAKAT TERHADAP PEMAKAIAN GIGI TIRUAN DI KECAMATAN TONDANO BARAT
}

\author{
${ }^{1}$ Fonda Padu \\ ${ }^{2}$ Bennedictus S. Lampus \\ ${ }^{3}$ Vonny NS. Wowor \\ ${ }^{1}$ Mahasiswa Program Studi Pendidikan Dokter Gigi Fakultas Kedokteran \\ Universitas Sam Ratulangi Manado \\ ${ }^{2}$ Fakultas Kedokteran Universitas Sam Ratulangi Manado \\ ${ }^{3}$ Program Studi Pendidikan Dokter Gigi Fakultas Kedokteran \\ Universitas Sam Ratulangi Manado \\ Email: milanfonda@yahoo.com
}

\begin{abstract}
Teeth are one of the important components in the mouth that has a function of speech and mastication process. Although the science and technology of dentistry allows preventing tooth decay as early as possible, but there are still many cases of tooth loss. Treatment with the use of dentures as a replacement for the loss of the teeth is very important, but not all the people who have lost teeth are wearing dentures. In Indonesia, there are many cases of tooth loss but not in proportion to the number of users denture. According to a survey there are still a few people who wear dentures. Knowledge is one of the factors that cause a person to do things. The purpose of this study is to describe the level of public knowledge of Tondano Barat about dentures. This descriptive type of reasearch with a crosssectiona study involving 67 respondents which is representative of a population of 3.295 people. Collecting data obtained through a questionnaire which includes characteristics of the respondents, level of knowledge about the use of denture. The results showed the level of public knowledge about the purpose of the use of denture is good with a percentage of $77,1 \%$ and the level of public knowledge about the benefits of the use of denture relatively good with a percentage of $71,4 \%$. The conclusion of this study, the average level of public knowledge about denture use is good.
\end{abstract}

Keywords: Public knowledge, use of denture

\begin{abstract}
Abstrak: Gigi geligi merupakan salah satu komponen penting dalam mulut yang berperan dalam proses bicara maupun pengunyahan. Walaupun ilmu dan teknologi kedokteran gigi memungkinkan mencegah kerusakan gigi sedini mungkin, namun masih saja banyak dijumpai kasus kehilangan gigi. Perawatan dengan pemakaian gigi tiruan sebagai pengganti daerah yang kehilangan gigi sangat penting, akan tetapi tidak semua orang yang kehilangan gigi memakai gigi tiruan. Di Indonesia banyak terdapat kasus kehilangan gigi namun tidak sebanding dengan jumlah pemakai gigi tiruan. Menurut survei yang ada, pemakai gigi tiruan masih sangat sedikit. Pengetahuan merupakan salah satu faktor penyebab seseorang dalam melakukan suatu tindakan. Penelitian ini bertujuan untuk mengetahui gambaran tingkat pengetahuan masyarakat di kecamatan Tondano Barat terhadap pemakaian gigi tiruan. Jenis penelitian ini bersifat deskriptif dengan pendekatan cross-sectional study yang melibatkan 67 responden yang merupakan perwakilan dari populasi sebesar 3.295 jiwa. Pengumpulan data diperoleh melalui kuesioner yang meliputi karakteristik serta tingkat pengetahuan masyarakat mengenai tujuan dan manfaat pemakaian gigi tiruan. Hasil penelitian menunjukkan tingkat pengetahuan masyarakat terhadap tujuan dari pemakaian gigi tiruan tergolong baik dengan persentase sebesar $77,1 \%$ dan tingkat pengetahuan masyarakat terhadap manfaat dari pemakaian gigi tiruan tergolong baik dengan persentase sebesar $71,4 \%$. Kesimpulan dari penelitian ini, rata - rata tingkat pengetahuan masyarakat terhadap pemakaian gigi tiruan tergolong baik.
\end{abstract}

Kata kunci:Pengetahuan masyarakat, pemakaian gigi tiruan 
Gigi geligi merupakan salah satu komponen penting di dalam mulut yang berperan dalam proses bicara maupun pengunyahan. Pada masa sekarang, walaupun ilmu dan teknologi kedokteran gigi memungkinkan untuk dapat mencegah kerusakan gigi Perubahan yang terjadi akibat kehilangan gigi berdampak pada penurunan efisiensi pengunyahan yang secara tidak langsung berpengaruh pada kesehatan umum seseorang. ${ }^{1}$ Kehilangan gigi geligi juga dapat menimbulkan dampak emosional dan fungsional serta dapat memengaruhi estetik. Akibat lainnya yaitu dapat berpengaruh pada ketidaknyamanan dan emosi pada kebanyakan orang. ${ }^{2,3}$ sedini mungkin, masih saja banyak dijumpai kasus kehilangan gigi.

Perawatan dengan pemakaian gigi tiruan sebagai pengganti daerah yang kehilangan gigi geligi sangat penting, namun tidak semua orang yang kehilangan gigi memakai gigi tiruan. ${ }^{2}$ Menurut survei Riskesdas pada tahun 2007, prevalensi pengguna gigi tiruan hanya sekitar 4,5\% dari jumlah populasi penduduk Indonesia yang ada. Sementara itu prevalensi kehilangan gigi di Indonesia mencapai 79\%. Kecilnya prevalensi pengguna gigi tiruan dipengaruhi oleh beberapa faktor, seperti mahalnya biaya pembuatan gigi tiruan, lamanya waktu yang dibutuhkan untuk pembuatan gigi tiruan, kurangnya pengetahuan masyarakat tentang manfaat pemakaian gigi tiruan, serta persepsi individu terhadap status kesehatan gigi. ${ }^{4}$ Pengetahuan merupakan salah satu faktor pendukung pada individu dalam melakukan suatu tindakan.

Dari hasil pengamatan sehari-hari yang dilakukan penulis di daerah sekitar tempat tinggal yang berlokasi di kecamatan Tondano Barat, terdapat banyak orang yang telah kehilangan gigi, namun jarang ditemukan yang telah memakai gigi tiruan.

Kecamatan Tondano Barat merupakan salah satu kecamatan yang berada di Kabupaten Minahasa dengan jumlah penduduk sebesar 18.588 jiwa. Masyarakat di kecamatan Tondano Barat memiliki tingkat pengetahuan yang berbeda-beda. Sebagian besar masyarakatnya adalah lulusan SMA.
Pengetahuan adalah merupakan hasil "tahu", dan ini terjadi setelah orang melakukan penginderaan terhadap suatu objek tertentu. Pengindraan terjadi melalui pancaindra manusia, yakni: indra penglihatan, pendengaran, penciuman, rasa, dan raba. Sebagian besar pengetahuan manusia diperoleh melalui mata dan telinga. Gigi tiruan adalah alat tiruan yang digunakan untuk menggantikan gigi yang telah hilang atau tanggal. Gigi tiruan disebut juga protesa, protesis atau restorasi, denture.

Tujuan penelitian ini adalah untuk mengetahui gambaran tingkat pengetahuan masyarakat terhadap pemakaian gigi tiruan di Kecamatan Tondano Barat.

\section{BAHAN DAN METODE}

Jenis penelitian ini bersifat deskriptif dengan pendekatan cross sectional study dan dilakukan di Kecamatan Tondano Barat pada bulan Februari - Juni 2012. ${ }^{5}$

Populasi dari penelitian ini ialah masyarakat yang berusia 18 sampai dengan 30 tahun di Kecamatan Tondano Barat sebanyak 3.295 orang.

Metode pengambilan sampel dilakukan dengan purposive sampling yaitu cara pemilihan sampel yang didasarkan pada pertimbangan, alasan, atau tujuan tertentu dari peneliti. Jumlah sampel dalam penelitian ini sebesar 67 responden.

Instrument penelitian yang digunakan dalam penelitian ini yaitu menggunakan lembar kuesioner. Data diolah dan disajikan dalam bentuk tabel kemudian dianalisis secara deskriptif berdasarkan hasil persentase. Terdapat dua kelompok pertanyaan yang menilai tentang pengetahuan masyarakat mengenai tujuan dan manfaat pemakaian gigi tiruan. Untuk mengukur pengetahuan masyarakat berdasarkan tujuan pemakaian gigi tiruan digunakan 4 pertanyaan. Setiap pertanyaan diberi dua pilihan jawaban yaitu "tahu” dan "tidak tahu” dimana skor untuk jawaban tahu adalah 2 dan skor untuk jawaban tidak tahu adalah 1 .

Untuk mengukur pengetahuan masyarakat berdasarkan manfaat pemakaian gigi tiruan digunakan 3 pertanyaan. Setiap 
Padu, Lampus, Wowor; Gambaran Tingkat Pengetahuan Masyarakat...

pertanyaan diberi dua pilihan jawaban yaitu "tahu" dan "tidak tahu" dimana skor untuk jawaban tahu adalah 2 dan skor untuk jawaban tidak tahu adalah 1. Hasil perhitungan skor disajikan dalam bentuk tabel dan skala dengan menggunakan persentase. Terdapat dua kategori untuk menilai hasil yang diperoleh yaitu "baik" jika total skor yang diperoleh lebih dari 50\% atau "kurang" jika total skor yang diperoleh kurang dari 50\%.

\section{HASIL PENELITIAN}

Responden dalam penelitian ini yaitu masyarakat di Kecamatan Tondano Barat yang berjumlah 67 responden yang didistribusikan menurut jenis kelamin (Tabel 1), menurut kelompok umur (Tabel 2), dan menurut tingkat pendidikan (Tabel 3).

Tabel 1. Distribusi responden menurut jenis kelamin

\begin{tabular}{ccc}
\hline Jenis Kelamin & Jumlah & \% \\
\hline Laki - laki & 39 & 58,21 \\
Perempuan & 28 & 41,79 \\
Jumlah & 67 & 100 \\
\hline
\end{tabular}

Tabel 2. Distribusi responden menurut kelompok umur

\begin{tabular}{ccc}
\hline Rentang Usia & $\begin{array}{c}\text { Jumlah } \\
\text { Responden (N) }\end{array}$ & $\begin{array}{c}\text { Persentase } \\
\mathbf{( \% )}\end{array}$ \\
\hline $18-20$ tahun & 11 & 16,41 \\
$21-23$ tahun & 16 & 23,88 \\
$24-26$ tahun & 22 & 32,84 \\
$27-30$ tahun & 18 & 26,87 \\
Total & 67 & 100 \\
\hline
\end{tabular}

Berdasarkan umur, responden paling banyak ialah pada rentang usia 24-26 tahun yakni sebanyak 22 orang (32,84\%) dan yang paling sedikit pada rentang usia 18-20 tahun yakni sebanyak 11 orang (16,41\%).

Berdasarkan tingkat pendidikan, responden paling banyak merupakan lulusan SMA dengan jumlah 35 responden (52,24\%) dan yang paling sedikit yaitu lulusan SD dengan jumlah 6 responden $\quad(8,96 \%)$ (Tabel 3).
Tabel 3. Distribusi responden menurut tingkat pendidikan

\begin{tabular}{ccc}
\hline $\begin{array}{c}\text { Pendidikan } \\
\text { Terakhir }\end{array}$ & Jumlah & $\mathbf{\%}$ \\
\hline SD & 6 & 8,96 \\
SMP & 12 & 17,91 \\
SMA & 35 & 52,24 \\
Perguruan Tinggi & 14 & 20,89 \\
Jumlah & 67 & 100 \\
\hline
\end{tabular}

Untuk pengetahuan responden mengenai tujuan pemakaian gigi tiruan didapatkan skor 413, maka digunakan rumus:

$$
\begin{gathered}
\mathrm{X} / \mathrm{Y} \times 100 \%=\mathrm{Z} \\
413 / 536 \times 100 \%=77,1 \%
\end{gathered}
$$

Skala Guttman untuk pengetahuan mengenai tujuan pemakaian gigi tiruan:

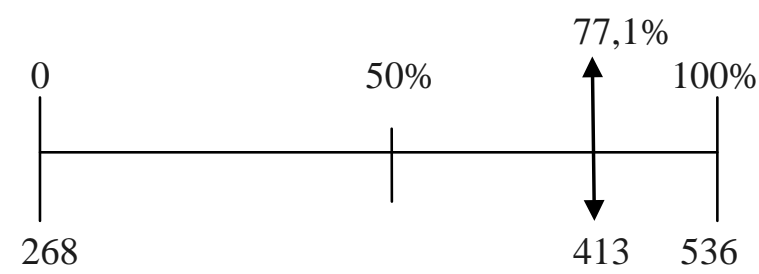

Dari hasil perhitungan di atas, bila dikategorikan dalam skala Guttman maka pengetahuan masyarakat di kecamatan Tondano Barat mengenai tujuan pemakaian gigi tiruan tergolong baik $(77,1 \%)$.

Untuk pengetahuan responden mengenai manfaat pemakaian gigi tiruan didapatkan skor 287, maka digunakan rumus:

$$
\begin{gathered}
\mathrm{X} / \mathrm{Y} \times 100 \%=\mathrm{Z} \\
287 / 402 \times 100 \%=71,4 \%
\end{gathered}
$$

Skala Guttman untuk pengetahuan masyarakat mengenai manfaat pemakaian gigi tiruan:

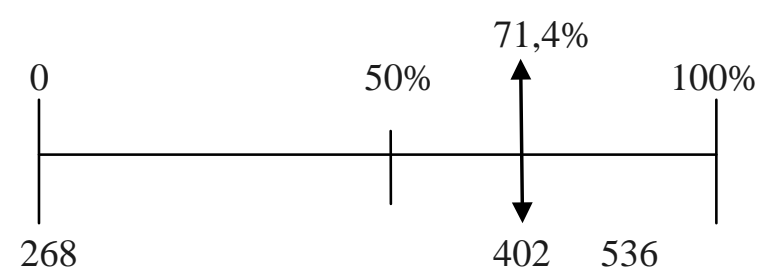


Dari hasil perhitungan di atas, bila dikategorikan dalam skala Guttman maka pengetahuan masyarakat di kecamatan Tondano Barat mengenai manfaat pemakaian gigi tiruan tergolong baik (71,4\%).

\section{BAHASAN}

Dalam penelitian ini, rata-rata perolehan skor tingkat pengetahuan responden terhadap pemakaian gigi tiruan secara keseluruhan termasuk pada kategori baik. Pengetahuan ini meliputi pengetahuan mengenai tujuan dan manfaat pemakaian gigi tiruan. Hasil penelitian ini menunjukkan bahwa hampir semua responden memiliki pengetahuan yang baik mengenai pemakaian gigi tiruan secara umum.

Dari hasil penelitian, 90\% responden tahu bahwa gigi tiruan bertujuan untuk mengisi daerah yang telah kehilangan gigi. Pengetahuan ini tergolong baik karena hampir semua responden tahu tujuan utama dari pemakaian gigi tiruan. Daerah yang telah kehilangan gigi jika tidak digantikan dengan memakai gigi tiruan maka akan memengaruhi fungsi lainnya, sehingga dengan pemakaian gigi tiruan maka tidak terdapat kekosongan pada lengkung rahang yang bisa berakibat pada fungsi bicara atau pengunyahan. Selain itu juga dengan memakai gigi tiruan maka migrasi gigi tetangga atau ekstrusi gigi antagonis akibat adanya ruang kosong dapat dihindari. Pengetahuan responden yang tergolong baik ini salah satunya dipengaruhi oleh usia dimana dengan semakin bertambahnya usia, maka pengetahuan dan pengalaman responden juga semakin bertambah.

Umur dan latar belakang pendidikan sangat berpengaruh terhadap kualitas pengetahuan seorang individu. Umur merupakan salah satu ciri kedewasaan fisik dan kematangan psikologis yang berkaitan dalam memberikan tanggapan atau respon terhadap objek yang ada di sekitarnya. Umur yang semakin dewasa akan lebih mudah memberikan tanggapan yang diperoleh baik melalui pendidikan maupun pengalaman-pengalaman lain. Dalam hal pemakaian gigi tiruan, salah satu penelitian menunjukkan bahwa orang yang lebih dewasa merasa kebutuhan pemakaian gigi tiruan lebih diperlukan dibandingkan dengan orang yang lebih muda. ${ }^{6}$

Untuk pertanyaan mengenai pemakaian gigi tiruan dapat mengembalikan fungsi pengunyahan, lebih dari 50\% responden mengetahui tujuan tersebut. Dari hasil tanya jawab diperoleh informasi bahwa responden tahu jika kehilangan gigi maka pengunyahan akan terganggu dan sebagian besar mengeluhkan terganggunya fungsi pengunyahan karena pada saat makan tidak bisa mengunyah makanan dengan maksimal sehingga berdampak juga pada proses penelanan dan pencernaan. Selain itu juga terdapat kesulitan terutama saat mengunyah makanan yang keras. Penelitian ini membuktikan pengetahuan masyarakat Kecamatan Tondano Barat tentang kehilangan gigi memengaruhi pengunyahan adalah baik.

Pertanyaan selanjutnya, hampir setengah dari jumlah responden mengetahui bahwa kehilangan gigi akan memengaruhi pengucapan. Peneliti berpendapat bahwa responden yang menjawab tahu akan dampak tersebut disebabkan karena responden merasakan langsung akibat dari kehilangan gigi terhadap pengucapan. Biasanya responden yang merasa terganggu adalah yang mengalami kehilangan gigi di bagian anterior. Sementara responden yang menjawab tidak tahu jika kehilangan gigi memengaruhi pengucapan umumnya tidak merasakan langsung akibat dari kehilangan gigi tersebut. Individu yang tidak mengalami gangguan dalam pengucapan setelah kehilangan gigi biasanya adalah yang mengalami kehilangan pada bagian posterior.

Tujuan pemakaian gigi tiruan selanjutnya adalah untuk memperbaiki estetika wajah. Tidak banyak responden yang tahu tentang tujuan pemakaian gigi tiruan ini. Gigi sulung yang tanggal terlalu dini atau pencabutan gigi permanen mengakibatkan asimetri wajah yang dapat mempengaruhi estetika wajah. ${ }^{7}$ Kehilangan gigi dalam jumlah banyak sangat mempengaruhi estetika wajah karena wajah akan tampak lebih tirus dan terlihat lebih tua 
Padu, Lampus, Wowor; Gambaran Tingkat Pengetahuan Masyarakat...

dari usia yang sebenarnya. Bentuk wajah yang berubah sangat memengaruhi estetik wajah. Dalam kehidupan sehari-hari bisa dilihat bahwa orang yang mengalami kehilangan gigi maka keindahan wajahnya akan berkurang. Meskipun hal di atas merupakan salah satu tujuan penting namun hasil penelitian ini hanya memperoleh skor rendah dengan persentase sebesar 30\%. Hal ini dipengaruhi oleh latar belakang pendidikan responden dimana informasi seperti ini biasanya hanya ditemui di jenjang pendidikan lebih tinggi atau dari media internet yang sebagian besar hanya mau diakses oleh mereka yang tingkat pendidikannya baik.

Pengetahuan sangat erat kaitannnya dengan pendidikan, dimana diharapkan seseorang dengan pendidikan tinggi akan semakin luas pengetahuannya. Pendidikan merupakan faktor penting yang menjadi salah satu dasar pada pengetahuan seseorang. Pernyataan ini tidak serta merta menjadi jaminan bahwa orang dengan lulusan perguruan tinggi mempunyai pengetahuan yang lebih baik dibanding yang bukan lulusan perguruan tinggi, salah satunya pengetahuan mengenai kesehatan gigi dan mulut. Seseorang berpendidikan rendah tidak mutlak berpengetahuan rendah pula. Peningkatan pengetahuan tidak hanya diperoleh lewat pendidikan formal, akan tetapi juga dapat diperoleh dari pendidikan non formal. Kurangnya pendidikan tentang pentingnya kesehatan mulut, perlunya perawatan preventif, konsekuensi mengenai kesehatan mulut merupakan halangan yang penting bagi kesehatan mulut. ${ }^{8}$

Pengetahuan masyarakat diperoleh dari berbagai hal yang dapat dilihat, dirasa, didengar, ataupun diraba. Pengetahuan merupakan faktor predisposisi atau faktor yang mempermudah bagi seseorang untuk terlaksananya suatu perilaku dalam hal ini perilaku kesehatan terhadap perawatan prosthodonsia. Perilaku kesehatan menurut Skinner merupakan suatu respon seseorang terhadap objek yang berkaitan dengan sakit, penyakit, serta sistem pelayanan kesehatan, dimana pelayanan untuk pemakaian gigitiruan juga termasuk dalam salah satu bentuk pelayanan kesehatan gigi dan mulut. ${ }^{9}$ Pengetahuan juga merupakan faktor pemicu terhadap perilaku yang menjadi dasar atau motivasi bagi tindakannya akibat tradisi atau kebiasaan, kepercayaan, tingkat pendidikan, dan tingkat sosial ekonomi. Pengetahuan masyarakat terhadap pemakaian gigi tiruan dapat diperoleh dari mana saja, meskipun individu tersebut tidak memakai gigi tiruan.

Pembahasan selanjutnya adalah mengenai manfaat pemakaian gigi tiruan. Sebagian besar responden tidak tahu bahwa dengan memakai gigi tiruan, bentuk wajah yang berubah akibat kehilangan gigi dapat kembali normal. Hal ini mengindikasikan bahwa masih sedikit responden yang paham kehilangan gigi dapat merubah bentuk wajah, tinggi muka, dan dimensi vertikal serta menyebabkan rahang prognasi. ${ }^{10}$ Individu yang telah kehilangan lebih dari satu gigi terutama gigi posterior bawah maka profil wajahnya akan berubah, mandibula akan tampak lebih maju. Dalam kehidupan sehari - hari pada individu yang telah kehilangan seluruh gigi terlihat rahang bawah lebih maju dari posisi normal. Dengan memakai gigi tiruan maka perubahan ini akan dapat diperbaiki sehingga hubungan antara rahang atas dan bawah dapat kembali seperti semula.

Gangguan sendi rahang dapat dicegah dengan memakai gigi tiruan merupakan manfaat selanjutnya, namun hanya sedikit responden yang tahu mengenai hal tersebut. Hanya 11 dari 67 responden yang mengetahui manfaat pemakaian gigi tiruan ini dan termasuk pada kategori kurang. Kehilangan gigi terutama pada daerah posterior berakibat pada mekanisme neuromuscular akan membentuk pola pergerakan baru rahang bawah untuk mengompensasi posisi gigi yang baru akibat ketidakserasian dengan gigi lainnya dalam fungsi mulut. Sisa gigi yang ada akan mencoba beradaptasi dengan pola pergerakan baru tersebut, dengan kemungkinan akan menimbulkan ketidakserasian dalam pergerakan. Adanya kontak prematur akan menyebabkan deviasi pergerakan rahang bawah yang akhirnya akan terjadi disfungsi sendi temporomandibular dan spasma otot 
yang bisa menyebabkan rasa nyeri. ${ }^{11}$ Bagi yang telah kehilangan gigi terutama gigi belakang akan merasakan tidak nyaman atau bahkan sakit pada bagian TMJ terutama ketika mengunyah makanan karena penyebaran tekanan kunyah yang tidak merata. Individu yang mengalami gangguan sendi dan telah memakai gigi tiruan, perlahan gangguan pada TMJ akan hilang sehingga tidak akan lagi merasakan nyeri atau sakit.

Selanjutnya, sebagian besar responden tahu bahwa perubahan penampilan dapat diperbaiki dengan memakai gigi tiruan. Dengan persentase hampir 90\% menunjukkan bahwa pengetahuan responden mengenai manfaat gigi tiruan yang berhubungan dengan perubahan penampilan tergolong baik. Responden tahu bahwa jika kehilangan gigi maka penampilan mereka akan menjadi tidak menarik karena tidak bisa bebas untuk berbicara atau tersenyum. Hal ini juga berkaitan dengan tujuan pemakaian gigi tiruan yaitu untuk memperbaiki estetik. Seseorang yang mengalami kehilangan gigi namun telah memakai gigi tiruan akan lebih percaya diri untuk berinteraksi dengan orang lain, tidak akan lagi merasa malu atau rendah diri saat berbicara atau tertawa di depan umum.

Secara rata-rata pengetahuan masyarakat di kecamatan Tondano Barat terhadap pemakaian gigi tiruan tergolong baik. Penelitian yang dilakukan Yosua di daerah Wanea menunjukkan hasil serupa, dimana pengetahuan masyarakat terhadap pemakaian gigi tiruan adalah baik. ${ }^{12}$ Hal ini didukung oleh tingkat pendidikan serta kemauan masyarakat untuk mencari informasi mengenai gigi tiruan baik dari sekolah, dokter gigi, maupun media elektronik. Penelitian Chandra di daerah Serdang menunjukkan hasil yang berbeda. Pengetahuan masyarakat tentang pemakaian gigi tiruan di daerah tersebut tergolong kurang. ${ }^{13}$ Hasil penelitian yang berbeda membuktikan bahwa tingkat pengetahuan masyarakat berbeda-beda. Hal ini selain dipengaruhi oleh latar belakang pendidikan juga dipengaruhi oleh informasi yang diperoleh masyarakat. Informasi tentang gigi tiruan dapat berasal dari mana saja baik media cetak maupun elektronik. Sering tidaknya sosialisasi yang dilakukan pihak terkait, dalam hal ini mengenai fungsi dan pemakaian gigi tiruan juga memegang peranan penting dalam meningkatkan pengetahuan masyarakat.

\section{SIMPULAN}

Pengetahuan masyarakat terhadap tujuan dan manfaat dari pemakaian gigi tiruan di kecamatan Tondano Barat tergolong baik.

\section{SARAN}

Bagi pemerintah kecamatan Tondano Barat melalui dinas kesehatan, agar dapat melakukan penyuluhan mengenai tujuan dan manfaat pemakaian gigi tiruan secara berkala sehingga masyarakat lebih teredukasi dan meningkatkan kesadaran masyarakat terhadap pemakaian gigi tiruan. Kesadaran yang meningkat diharapkan bisa menggerakkan masyarakat untuk memakai gigi tiruan.

Bagi mahasiswa, perlu dilakukan penelitian lebih lanjut untuk mengevaluasi tingkat pengetahuan masyarakat sehingga diperoleh gambaran mengenai kesadaran masyarakat untuk memakai gigi tiruan.

\section{DAFTAR PUSTAKA}

1. Micni J. Rehabilitasi fungsi kunyah dengan dental implant. [Internet]. 2011 [diakses 22 Okt 2011]. Tersedia dari: http://dentiadental.com/2011/articles/rehabilitasifungsi-kunyah-dengan-dental-implant/

2. Jubhari EH. Thinking pattern of first grade students towards edentulous replacement. Dent J (Maj Ked Gigi) 2007; 40. p. 65 - 9

3. Sari D. Hubungan status gizi dengan kehilangan gigi pada lansia di Panti Jompo Abdi / Dharma Asih Binjai. [Internet] 2010 [diakses 22 Okt 2011]. Tersedia dari: http://repository.usu.ac.id/bitstream/123456 789/22619/6/pdf

4. Hermina P. Alasan masyarakat kelurahan Sario Tumpaan tidak menggunakan gigitiruan. [Internet] 2013 [diakses $15 \mathrm{Jul}$ 2014]. Tersedia dari: http://download. portalgaruda.org/article.php?article=10741 $5 \& v a l=1000$ 
Padu, Lampus, Wowor; Gambaran Tingkat Pengetahuan Masyarakat...

5. Riyanto A. Metodologi penelitian kesehatan. Yogyakarta: Nuha Medika; 2011

6. Shigli K, Hebbal M, Angadi GS. Attitudes towards replacement of teeth among patients at the institude of dental sciences. Belgaum, India. J Dent Educ 2007; 71 (11). p. $1467-75$

7. Akeel R. Attitudes of Saudi male patients toward the replacement of teeth. Prosthet Dent. 2003; 90. p. $571-7$

8. Mar'at S, Kartono LI, editors. Perilaku Manusia : Pengantar Singkat Tentang Psikologi. Bandung: PT Refika Aditama; 2006. h. 2

9. Magdarina DA. Percentage of The Artificial Denture Usage in Indonesia. Media Litbang Kesehatan. 2010; 20 (2)

10. Walianto S. Asimetri Dental dan Wajah. [Internet] 2011 [diakses 25 Okt 2011]. 5
(2). Tersedia dari: http://unmaslibrary.ac.id/jurnal_unmas/0.pdf

11. Dampak kehilangan gigi. [Internet] 2010 [diakses 25 Okt 2011]. Tersedia dari: http://lib.ui.ac.id/file?file=digital/127524R17-PRO-173 Hubungan\%20antaraLiteratur.pdf

12. Randa Y. Pengetahuan dan sikap masyarakat terhadap pemakaian gigi tiruan di kelurahan Pakowa kecamatan Wanea. Dentire Journal. 2013; 1 (2). h. 38-42

13. Chandra H. Persepsi masyarakat terhadap pemakaian gigitiruan di desa Ujung Rambung kecamatan Pantai Cermin kabupaten Serdang Bedagai. Skripsi: Fakultas Kedokteran Gigi Universitas Sumatera Utara ; 2010. Tersedia dari: URL: http: //repository.usu.ac.id/handle/ 123456789/20284 